\title{
Evaluation of the parameters of the radioactive and convective drying of three cultivars of yam (Dioscorea alata $\mathrm{L}$. )
}

\author{
Laurette Brigelia NKELETELA ${ }^{1}$, André KIMBONGUILA ${ }^{1}{ }^{2^{*}}$ Armelle BANKEDILA BOUANGA $^{1}$, Wilfrid \\ MAYEMBO $^{1}$, Louis MATOS ${ }^{1}$, Idriss MEGANEH WAISS, Jeremy PETIT ${ }^{2}$, Jean Mathurin NZIKOU ${ }^{1}$, Joël \\ SCHER ${ }^{2}$.
}

1 Engineering Laboratories of Industrial Processes, ENSP, University Marien Ngouabi, BP 69, Brazzaville, Republic of the Congo. BP69 - Brazzaville, Republic of the Congo.

2 University of Lorraine, LIBio (Laboratory of Biomolecules Engineering), F-54000 NANCY, France.

*University Marien Ngouabi BP 69 - E-mail: kimbothluc@gmail.com

Correspondence Author: André KIMBONGUILA ${ }^{1,2^{*}}$, University of Lorraine, LIBio (Laboratory of Biomolecules Engineering), F-54000 NANCY, France.

*University Marien Ngouabi BP 69 - E-mail: kimbothluc@gmail.com

Received date: 18 May 2019, Accepted date: 26 June 2019, Online date: 28 June 2019

Copyright: (C) 2019 André KIMBONGUILA1 et al, This is an open-access article distributed under the terms of the Creative Commons Attribution License, which permits unrestricted use, distribution, and reproduction in any medium, provided the original author and source are credited.

\begin{abstract}
The drying process occupies a very important place in the yam conservation process. It is therefore essential to control the drying parameters of this tuber to have a dry product of good quality. This work aims to evaluate the radiative drying at power $(140,280,420 \mathrm{~W})$ and convection at temperatures $\left(60,70,80^{\circ} \mathrm{C}\right)$ to estimate the diffusion coefficient and activation energy of three cultivars yam respectively Ngumvu (white yam), Mbungu menga (purple yam) and Nkula (white purple yam); and their influence on the drying mode. The results showed that power and temperature are variables that influence the drying kinetics of these cultivars. When power and temperature increase the drying time decreases. For both influencing factors, only the power significantly reduces the drying time. The diffusion coefficient for the three cultivars of yam varies between $6.58 .10^{-9}$ and $2.03 .10^{-8}\left(\mathrm{~m}^{2} / \mathrm{s}\right)$ with the increase in power and between $3.08 .10^{-10}$ and $4.98 .10^{-10}\left(\mathrm{~m}^{2} / \mathrm{s}\right)$ at temperatures of 60,70 and $80^{\circ} \mathrm{C}$. Values of activation energy $23.59 ; 20.47 ; 28.03(\mathrm{KJ} / \mathrm{mol})$ respectively for cultivars Ngumvu, Mbungu menga and Nkula expressed the effect of temperature on the diffusion coefficient. The Nkula cultivar has a significant influence on both drying modes because the lower the power and the temperature, the less is the drying time with a difference ranging from 90 to 180 seconds at $P_{1}=140 \mathrm{~W}$ and 20 to 30 minutes at $T_{1}=60^{\circ} \mathrm{C}$ compared to the cultivar Mbungu menga and Ngumvu. Among the semi empirical models considered, Demir model was estimated to be the most appropriate for describing the behavior of the three yam cultivars during the two drying modes whose values of the statistical parameters of the model are respectively: $R^{2}=0.9946 ; \chi^{2}=0.00065$; $R M S E=0.002552$ for the radiative drying and $R^{2}=0.99974 ; \chi^{2}=0.0000286$; $R M S E=0.00535$ for convective drying. The experimental conditions studied allowed us to stabilize the power and the drying temperature of these three cultivars by means of the mathematical models since at power of $140 \mathrm{~W}$ and at $80^{\circ} \mathrm{C}$ the model of Demir and al. influenced both modes of drying.
\end{abstract}

Keywords: Radioactive, convective, coefficient-diffusion, energy-activation, model semi-empirical.

\section{INTRODUCTION}

The yam Dioscorea alata of the family of Dioscoreaceae constitutes the base of the food in much of tropical countries. In Congo, as in its surface of origin Indo-Faintness, Dioscorea alata does not meet apart from the cultures and is cultivated much in the Southern areas of the country. However, its mode of production remains extensive and quasi-artisanal. It is the fact, in the majority of the cases, women individual or gathered within the structurally weak country organizations and consequently, incompetents to generate convincing results. By integrating the serious constraints of storage, one consequently includes/understands the passion still mitigated for the culture of the yam. Its productivity, its transformation, its consumption and its profitability still offer great possibilities for improvement.

In addition, Dioscorea alata is most widespread all over the world because it is easy to store, and moreover became the basic food significant. Also, drying can offer adequate solutions for the conservation of the yam.

The influence of the temperature, the relative humidity and cutting on the kinetics of drying of Dioscorea alata was also studied Hao-Yuju and al. (2015). 
The main objective of this work is the conservation of yam Dioscorea alata by means of radiative and convective drying in order to avoid post-harvest losses by studying the effect of power, temperature on kinetics and drying speed. to estimate diffusion coefficient, activation energy and cultivar influence on the drying mode to determine the best drying parameters. A mathematical model has been chosen to best simulate the kinetics of drying.

\subsection{Vegetable material}

\section{MATERIAL AND METHOD}

The yams were taken in the fields located at $3 \mathrm{~km}$ of Districk de Madingou and conveyed in Brazzaville then preserved at Laboratory LVAR of the ENSP; on a straw mattress with $1 \mathrm{~m}$ of the ground in the period the June 2018 at August 2018 . The cultivars used are identified according to their vernacular name:

$\checkmark$ Ngumvu (in laari); Lernbié (in téké); Massambrela (in vili); Subglobuleux tubers, of approximately $20 \mathrm{~cm}$ length and 10$15 \mathrm{~cm}$ diameter ;

$\checkmark$ Mbungu menga (in laari), Gâtsuélé (in téké), Kikila(en beembe), Kipanchimenge (in vili), Muhanda (in kaamba); Subglobuleux tubers, of approximately $20 \mathrm{~cm}$ length and $10-15 \mathrm{~cm}$ diameter ;

$\checkmark \quad$ Nkula (in beembé); Subglobuleux tubers, of approximately $18 \mathrm{~cm}$ length .

\subsection{Preparation of the sample}

The tubers of yam are peeled and cut out in plates of form parallelepiped $(L=4 \mathrm{~cm}, 1=3 \mathrm{~cm}$ and $\mathrm{E}=0,5 \mathrm{~cm}) \mathrm{using}$ a $\mathrm{knife}$ and of a scale (of $30 \mathrm{~cm})$.

\subsubsection{Radioactive drying:}

Radioactive drying indicates degradation by dissipation of part of the energy transported by the electromagnetic wave.

The microwave oven used is of mark GEEPAS with a capacity of $740 \mathrm{~W}$, consisted of a generator of wave which produces the electromagnetic waves and of a guide of waves which is used to transfer the electromagnetic waves from the generator towards the enclosure as application from the product to be treated.

The sample to dry beforehand to peel and dimensioned is weighed on a balance of precision $(0,001 \mathrm{~g}$ near).This mass is noted Mo; then placed in the furnace microwave while regulating time and the power. We followed the evolution of the mass of the plates of yam to the powers $(140,280$ and $420 \mathrm{~W})$. The plates are weighed all the thirty seconds until obtaining a constant mass.

\subsubsection{Convective drying:}

The drying oven of the type LABOLAN with a capacity of $250^{\circ} \mathrm{C}$ was used and dimensions of the interior room are $300 \times 280 \times 275 \mathrm{~mm}$. The temperature is controlled by the means of an electronic regulator. The follow-up of the evolution of the mass of the plates was carried out at the temperatures $\left(60,70\right.$ and $\left.80^{\circ} \mathrm{C}\right)$. The product is weighed all the ten minutes until obtaining a constant mass.

\subsection{Estimate of the coefficient of diffusion}

Effective diffusivity makes it possible to describe, analyze and characterize drying Doymaz and al. (2002). With this intention, one uses the equation of the second law of Fick which the analytical solution was developed by Crank, by supposing that the distribution of initial moisture is uniform, external resistances are negligible and uniform and constant diffusion according to the equation:

$$
\frac{\bar{M}-M e}{M o-M e}=\frac{8}{\pi^{2}} \sum_{n=0}^{\infty} \frac{1}{(2 n+1)} \exp \left[-(2 n-1)^{2} \frac{\pi^{2}}{4} \frac{D t}{L^{2}}\right]
$$

The solution takes into account: water content initial M0, water content with balance Me and the thickness of the sample (L).Simplifying the equation (1) by taking the first term of the solution of series and by supposing $\mathrm{Me}=0$ :

$$
M R=\frac{\bar{M}}{M o}=\frac{8}{\pi^{2}} \exp \left[-\frac{\pi^{2}}{4} \frac{D t}{L^{2}}\right]
$$

As drying arrives only on one surface of the sample, the thickness L in the equations (1) and (2) is replaced by L/2.

$$
-\frac{d M}{d t}=K(M-M e)
$$

\subsection{Estimate of the energy of activation}

The energy of activation is energy necessary to the vaporization of a quantity of water during drying. It is the relation between the temperature and mass diffusivity by the law of Arrhenius Doymaz and al. (2002). 


$$
D=D o \times e^{\left(-\frac{E a}{R T}\right)}
$$

With: D0 the Arrhenius factor, the energy of activation (Ea), the temperature (T) and the constant of perfect gases (R).

The energy of activation can be calculated starting from the slope of the equation (5) Doymaz and al. (2002):

$$
\operatorname{Ln} D=\operatorname{Ln} D o-\left(\frac{E a}{R T}\right)
$$

\subsection{Models semi-empirical}

This point consists in seeking the mathematical application which simulates best the studied phenomenon. One records in the literature an abundance of mathematical models in the form of empirical or semi-empirical relations to follow the curves of kinetics of drying.

Five semi-empirical models were used to describe the variation of the water content reduced according to the time of each cultivar (table 1).

\section{Table 1: Various models semi-empirical}

\begin{tabular}{|l|l|}
\hline Name of the model & Expression of the model \\
\hline Newton & MR. $=\exp (-\mathrm{kt})$ \\
\hline Two terms & MR. $=$ a.exp $(-\mathrm{kt})+$ b.exp $\left(-\mathrm{k}^{\prime} \mathrm{t}\right)$ \\
\hline Midilli-Kucuk & MR. $=$ a.exp $(-\mathrm{kt})+\mathrm{LT}$ \\
\hline Henderson and Padis & MR. $=$ a.exp $(-\mathrm{kt})$ \\
\hline Demir et al. & MR. $=$ a.exp $(-\mathrm{kt})^{\mathrm{n}}+\mathrm{b}$ \\
\hline
\end{tabular}

The various equations of table 1 give the evolution of the water content reduced in the course of time, defined by the following equation:

MR. $=\mathrm{M} / \mathrm{M}_{0}$

The parameters of appreciation of the quality of smoothing of the experimental results are the coefficient of determination $\left(\mathrm{R}^{2}\right)$, the ki-square $\left(\chi^{2}\right)$ and the square root of the average quadratic error (RMSE) 'RootMean Square Error '. These parameters are Calculate according to the relations:

$$
\begin{gathered}
\chi 2=\frac{\sum_{i=1}^{N}(M R e i-M R p i)^{2}}{N-n} \\
R M S E=\left\lfloor\frac{1}{N} \sum_{i=1}^{N}(M R e i-M R p i)^{2}\right\rfloor^{1 / 2}
\end{gathered}
$$

Where $\mathrm{MR}_{\mathrm{e}}$, is the $\mathrm{i}^{\mathrm{ème}}$ experimental value, MRpi, the $\mathrm{i}^{\mathrm{ème}}$ value predicted by the model;

$\mathrm{N}$ : the number of observations and $\mathrm{n}$ : the number of constants of the model.

The model is declared better, when the value of the coefficient of determination $\left(\mathrm{R}^{2}\right)$ is largest and the values of Khi-square $\left(\chi^{2}\right)$ and the weakest RMSE Akpinar and al. (2008).

\subsection{Statistical analysis}

The analysis and data processing was performed using the Excel 2013 spreadsheet. The curves and the coefficient of determination $\left(\mathrm{R}^{2}\right)$, Chi-square $(\chi 2)$ and RMSE values to estimate the efficiency of the semi-linear models empirical studies were performed using the ORGINPRO8 software.

\section{RESULTS AND DISCUSSION}

\subsection{Effect of the power and the temperature on the kinetics of drying}

The effect of the power and the temperature on the kinetics of drying is schematized in figures 1 and 2 which show that the power and the temperature have an influence on the evolution of the water content during drying.

The analysis of the curves of the variation of the water content of the three cultivars of yam according to time indicates that drying proceeds in decreasing phase exponential until balance, which joined the results of the literature Tulek (2011).

In the first time, one examines a strong interstitial water evaporation of the product for the three powers and temperature. The water which evaporates on the surface of the product constitutes interstitial water renewed by the capillary rise of interstitial water interns, as indicates it also Lahmari and al. (2012).

In the second time, the evaporation of water starts to decrease. The deceleration starts when there is no more interstitial water on the surface. One thinks of a ' face of vaporization' which is inserted gradually in the product, who corresponds well to work of.

These exchanges are less and less significant as drying is done, because the quantity of water which one can withdraw from the product is weaker and the difference in water content between the product and the air is increasingly weak (stabilization of weight), like it still confirmed Lahmari and al. (2012).

The time of oven drying microwave varies $270 \mathrm{~s}(4,5 \mathrm{~min})$ for $\mathrm{P}_{3}=420 \mathrm{~W}$ and of $1380 \mathrm{~s}$ ( $\left.23 \mathrm{~min}\right)$ for $\mathrm{P}_{1}=140 \mathrm{~W}$. The duration of drying of the cultivar Ngumvu is significant for all the powers of dryings compared to the others. That can be explained by its strong water content of about $75,82 \%$. The time of drying to the Drying oven varies 230 minutes for $\mathrm{T}_{3}=80^{\circ} \mathrm{C}$ and 380 minutes for $\mathrm{T}_{1}=60^{\circ} \mathrm{C}$. 


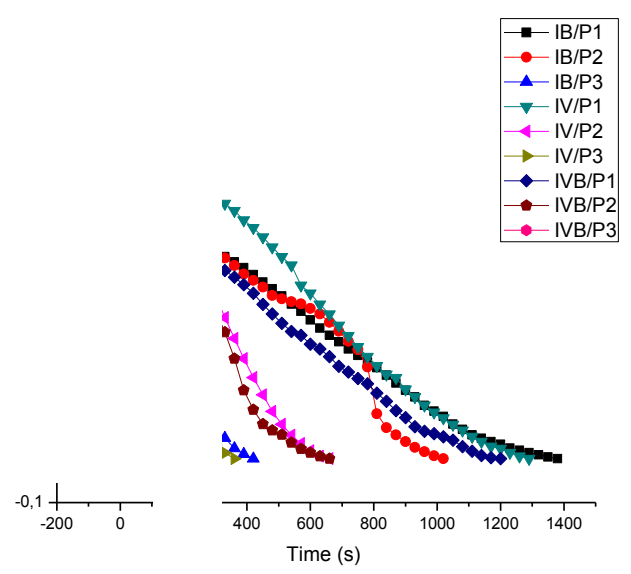

Figure 1: Influence power on the kinetics of three cultivars of Dioscorea alata L.

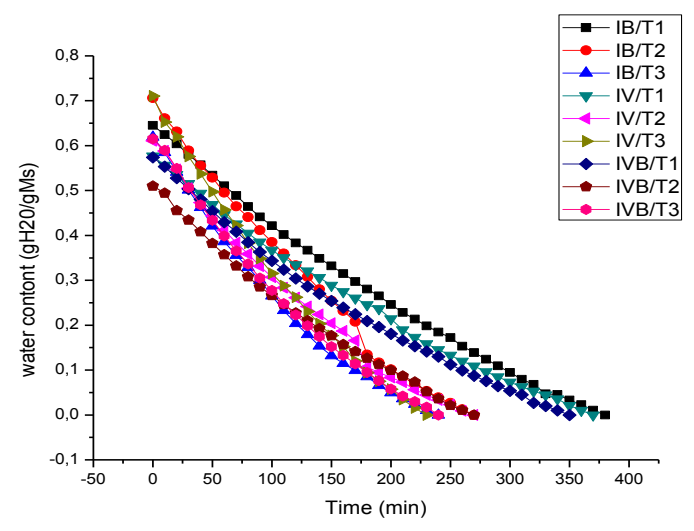

Figure 2: Influence temperature on the kinetics of three cultivars of Dioscorea alata $\mathbf{L}$.

\subsection{Effect of the power and the temperature on the speed of drying}

The curves of speed of drying with different power and temperature obtained for the three cultivars from yam studied are represented on figures 3 to 8 .

We note the absence of the phase of drying to constant pace for the two modes of drying and the absence of the phase of temperature setting for drying with the drying oven. Radioactive drying is done according to two phases: the temperature setting and the phase with decreasing pace and the drying convective are made in a decreasing way. What shows that the surface of material in contact with the air of drying is not fed any more out of interstitial water.

The surplus of energy is converted into significant heat and the temperature of the product (thus its vapor pressure) rises, initially surfaces some, then in the center until tending asymptotically towards the temperature of the air. Water migrates more and more with difficulty in the product and the internal transfer of matter becomes the limiting phenomenon. The diffusivity of water varying much with the water content, the dry product is increasingly impermeable with water.

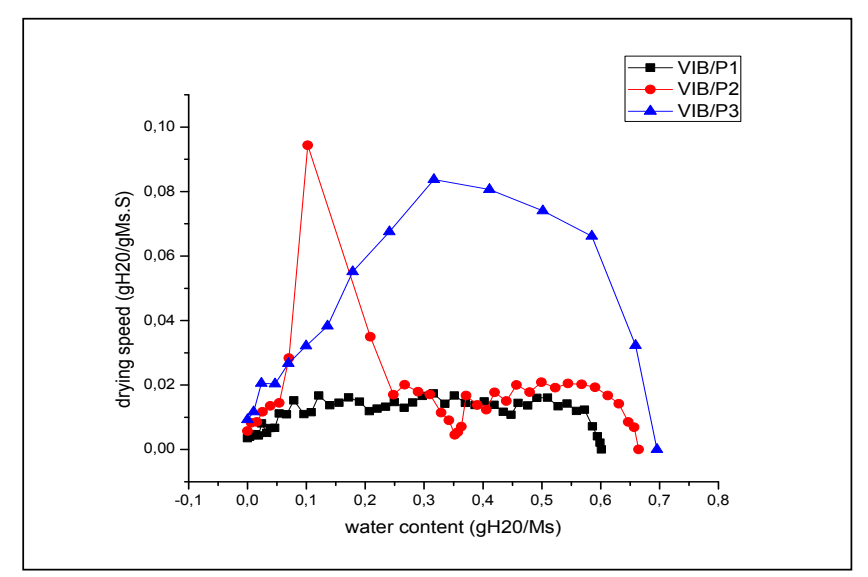


Figure 3: Effect of power on the speed Ngumvu cultivar (IB)

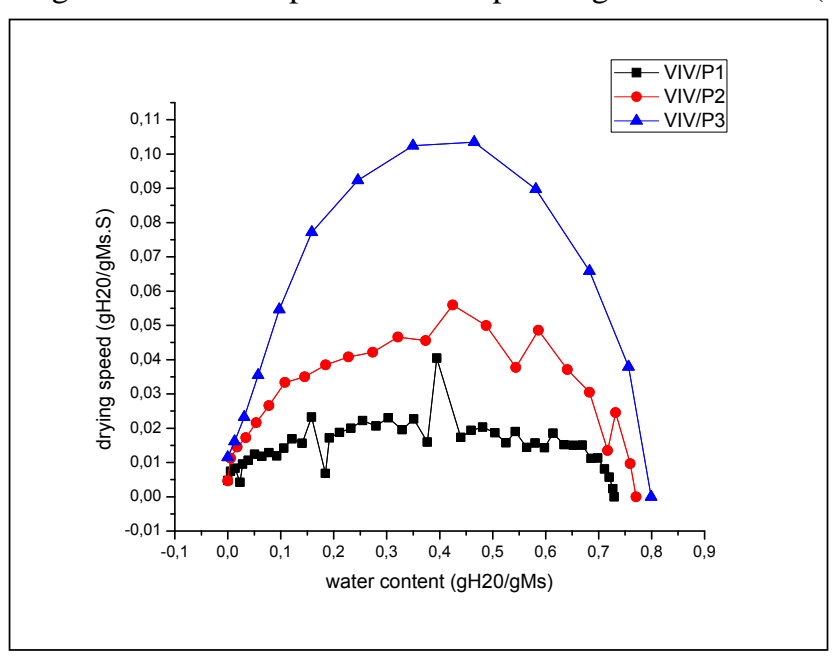

Figure 4: Effect of power on the speed of cultivar Mbungu menga (IV)

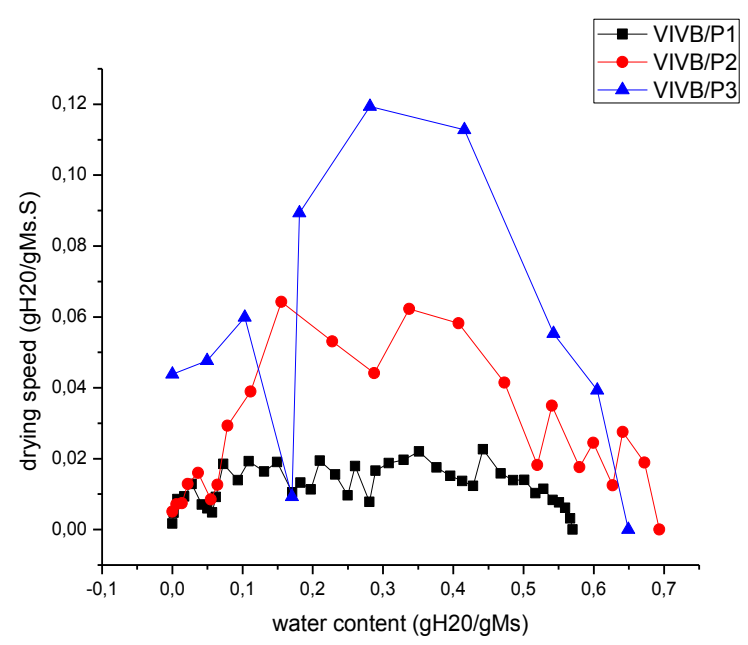

Figure 5: Effect of power on the speed of the Nkula cultivar (IVB).

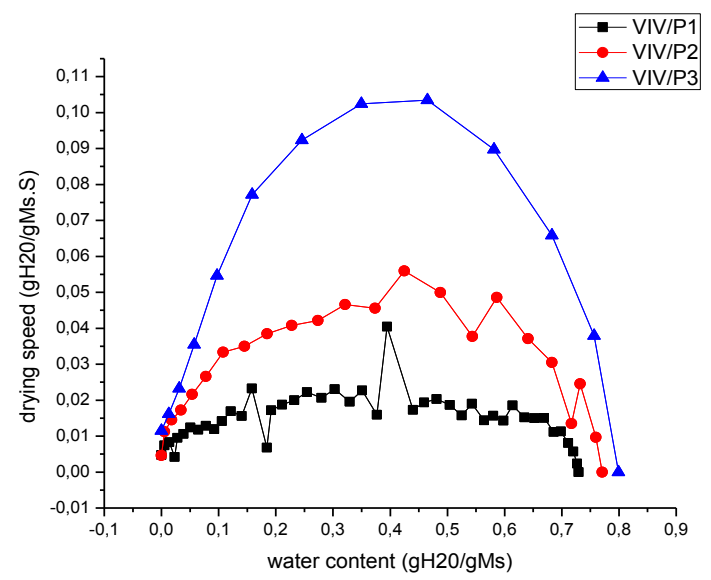

Figure 6: Effect of temperature on dryind speed of Ngumvu cultivar (IB). 


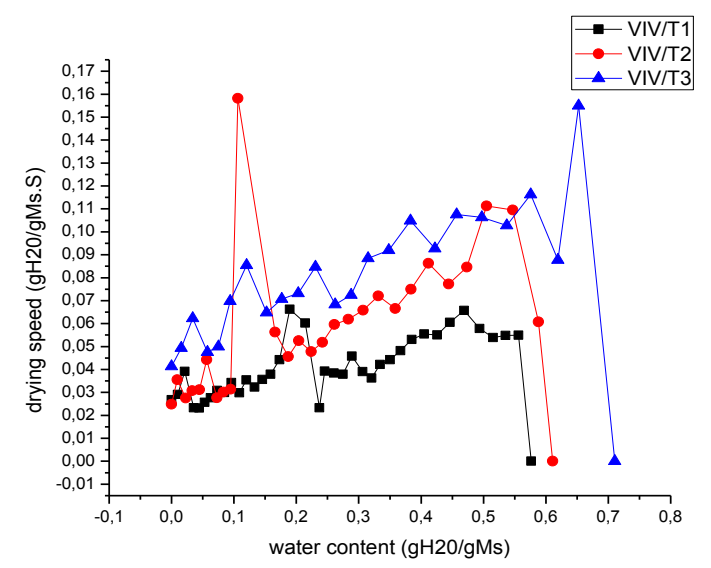

Figure 7: Effect of temperature on the drying speed of the cultivar Mbungu menga (IV).

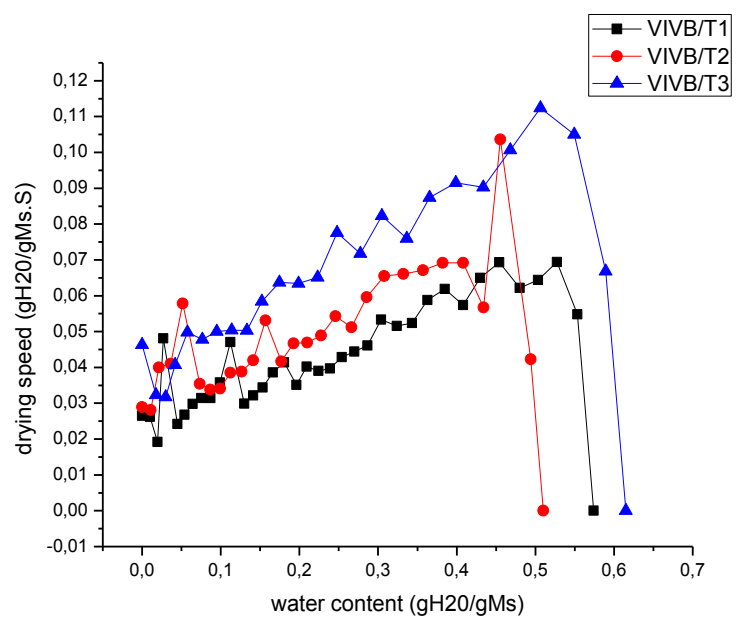

Figure 8: Effect of temperature on grying speed of cultivar Nkula (IVB).

\subsection{Influence cultivar on the two modes of drying}

By considering figures 9 and 10, we note that the cultivar Nkula (yam purple white) has a significant influence on the two modes of drying bus plus the power and the temperature are low, less is the time of drying with a going variation from 90 to 180 seconds with $\mathrm{P}_{1}=140 \mathrm{~W}$ and 20 to 30 minutes with $\mathrm{T}_{1}=60^{\circ} \mathrm{C}$ compared to the cultivar Mbungu-menga (yam purple) and Ngumvu (yam white).

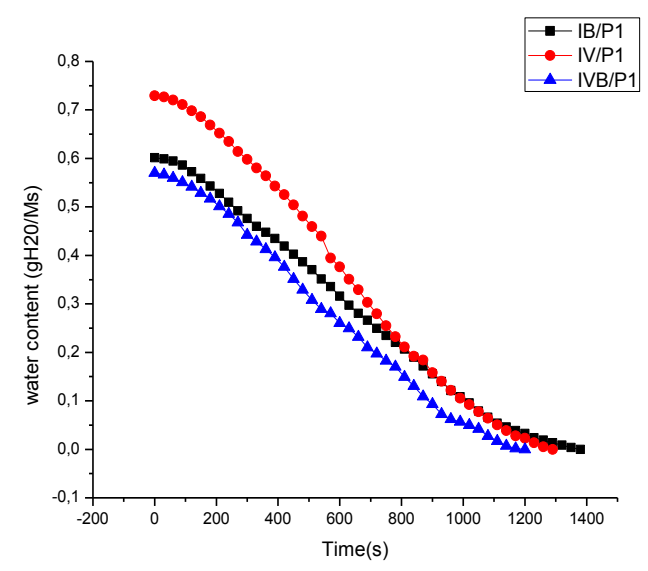

Figure 9: Influence of cultivars on drying power 


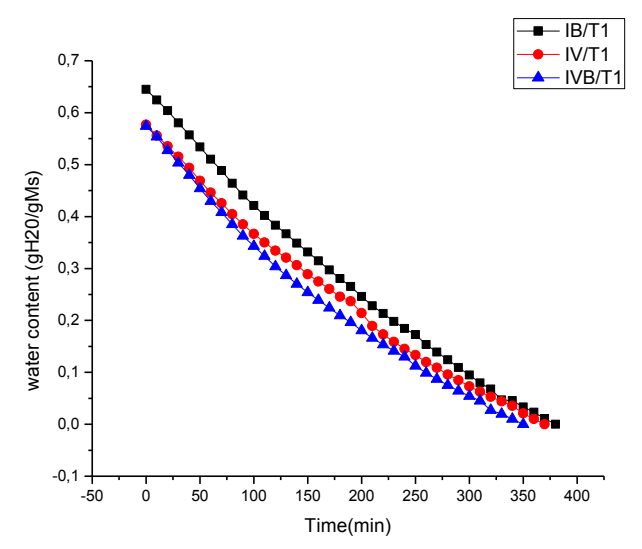

Figure 10: Influence of cultivars on the drying temperature

\section{4 .The coefficient of diffusion}

The experimental results can be treated by the equation of the diffusion of Fick. For the long periods of drying (MR. $<0.6$ ), the equation (2) can be simplified with the first term by a series. Thus, the catch of the Napierian logarithm in the two members of the equation (2) gives the following relation:

$$
\operatorname{Ln}(M R)=\operatorname{Ln}\left(\frac{8}{\pi^{2}}\right)-\left(\frac{\pi^{2} D t}{4 L^{2}}\right)
$$

The coefficient of diffusion for each power and temperature of drying was calculated in substituent the experimental data in the preceding equation. It is given by tracing the experimental data of drying in terms of Ln (MR) according to the time of drying. The layout of the equation (8) gives a straight line of slope:

$$
K=\frac{\pi^{2} D e f f}{4 L^{2}}
$$

The values of the coefficient of diffusion for the various powers and temperatures obtained are consigned in Table 2. The results show that the coefficient of diffusion increases with the increase in the power and the temperature of drying of the products Goyal and al. (2007). That implies that the increase in the power and temperature accelerates the transfer and the elimination of water in the product.

The majority of the agricultural produce (92\%) have a mass diffusivity in the range $10^{-12}$ to $10^{-8}\left(\mathrm{~m}^{2} / \mathrm{s}\right)$ Amina Menasra and al., (2015).

The coefficient of diffusion of the three cultivars of yam to powers 140,280 et $420 \mathrm{~W}$ varies from $\mathbf{6 , 5 8 . 1 0} \mathbf{5 0}^{-\mathbf{9}} \mathbf{t o} \mathbf{2 , 0 3 . 1 0 ^ { - 8 }} \mathbf{m}^{2} / \mathbf{s}$ and at temperatures 60,70 and $80^{\circ} \mathrm{C}$ varies in the range de $3,08.10^{-10}$ to $4,98.10^{-10} \mathrm{~m}^{2} / \mathrm{s}$. These been worth is in agreement with the general range for the drying of the foodstuffs.

\begin{tabular}{|c|c|c|c|c|c|c|c|c|}
\hline \multirow{2}{*}{\multicolumn{2}{|c|}{ Cultivars }} & \multicolumn{3}{|l|}{$\mathbf{T}\left({ }^{\circ} \mathbf{C}\right)$} & \multirow[t]{2}{*}{ Ea $(\mathrm{KJ} / \mathrm{mole})$} & \multicolumn{3}{|l|}{$\mathbf{P}(\mathbf{W})$} \\
\hline & & 60 & 70 & 80 & & 140 & 280 & 420 \\
\hline \multirow[t]{3}{*}{$\operatorname{Deff}\left(\mathrm{m}^{2} / \mathrm{s}\right)$} & IB & $3,08 \times 10^{-10}$ & $4,48 \times 10^{-10}$ & $4,98 \times 10^{-10}$ & 23,59 & $6,58 \times 10^{-09}$ & $7,09 \times 10^{-09}$ & $1,77 \times 10^{-08}$ \\
\hline & IV & $3,12 \times 10^{-10}$ & $4,52 \times 10^{-10}$ & $4,73 \times 10^{-10}$ & 20,47 & $6,58 \times 10^{-09}$ & $1,29 \times 10^{-08}$ & $2,03 \times 10^{-08}$ \\
\hline & IV/B & $3,34 \times 10^{-10}$ & $4,01 \times 10^{-10}$ & $4,56 \times 10^{-10}$ & 28,03 & $7,35 \times 10^{-09}$ & $1,39 \times 10^{-08}$ & $1,49 \times 10^{-08}$ \\
\hline
\end{tabular}

Table 2: Influence power and temperature on the coefficient of diffusion.

With: IB= white yam (Ngumvu); IV= purple yam (Mbungu menga) ; IV/B= white purple yam (Nkula)

\subsection{The energy of activation}

From the values obtained of effective diffusivity for various temperatures, the LnDeff function was traced according to $1 / \mathrm{T}$ to evaluate the energy of activation (figure 11). The value of the energy of activation for the three cultivars of yam obtained are respectively: 23,$59 ; 20,47 ; 28,03(\mathbf{K J} / \mathbf{m o l})$ Ngumvu, Mbungu menga (yam purple) and Nkula. These values are in agreement with the literature because the values of the energy of activation for the majority of the food matters are in the range 12,7 to 110 $\mathbf{k J} / \mathbf{m o l}$. Amina Menasra and al., (2015).

The value of the energy of activation $23,59 \mathrm{KJ} / \mathrm{mol}$ of the variety Ngumvu is near to that of potato $23,61 \mathrm{Kj} / \mathrm{mol}$ (variety Russet) Srikiatden and al., (2006). That of the variety Nkula $28,03 \mathrm{KJ} / \mathrm{mol}$ is close to the values $28,36 \mathrm{~kJ} / \mathrm{mol}$ for the carrot Doymaz (2006). 


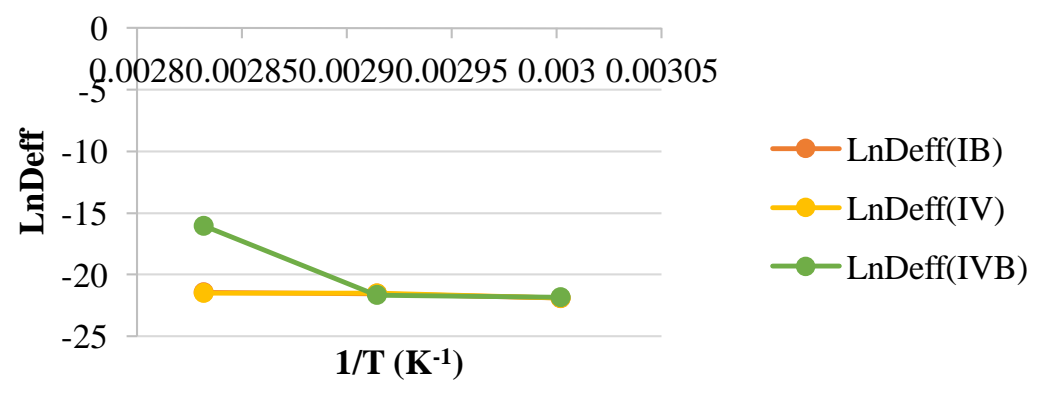

Figure 11: Evolution of LnDeff according to 1/T for different cultivars.

Table 3: comparison of the value of the energy of activation with those of the literature

\begin{tabular}{|c|c|c|}
\hline Product & $\begin{array}{lll}\begin{array}{l}\text { Energy } \\
(\mathrm{KJ} / \mathrm{mol})\end{array} & \text { of } & \text { activation } \\
\end{array}$ & References \\
\hline D. alata (Ngumvu) & 23,59 & \multirow[t]{3}{*}{ Present work. } \\
\hline D. alata (Mbungu menga) & 20,47 & \\
\hline D. alata (Nkula) & 28,03 & \\
\hline D. alata & 29,528 & Hao-Yuju and al.(2015) \\
\hline Potato (Russet) & 23,61 & Srikiatden and al.(2006) \\
\hline Round mint & 62,96 & Doymaz (2006) \\
\hline Whole glands of the oaks & 65,96 & \multirow{4}{*}{$\begin{array}{lll}\text { Amina } & \text {.Menascra } & \text { and } \\
\text { al.(2015) } & & \end{array}$} \\
\hline Peeled glands & 34,17 & \\
\hline Half peeled glands & 29,88 & \\
\hline Powder glands & 22,59 & \\
\hline
\end{tabular}

\subsection{Semi-empirical model}

Tables 4 and 5 show the statistical results of the models used during radiative and convective drying. In the tables, only the results that seem important are highlighted by the different colors:

$\checkmark$ Red indicates the model that has made the right adjustments;

$\checkmark$ Green indicates the pattern that comes after;

$\checkmark \quad$ Blue indicates the pattern that gave the wrong adjustments.

\subsubsection{Modeling of the water content reduced during radioactive drying}

The values of the statistical parameters used to consider the effectiveness of the models semi-empirical in order to describe the behavior of different the cultivars from yam (Ngumvu, Mbungu-menga and Nkula), during radioactive drying, are presented in table 4.

Table 4: values of the statistical parameters of the models during radioactive drying

\begin{tabular}{|c|c|c|c|c|c|}
\hline Cultivar & Mode & Power $(W)$ & $\mathbf{R}^{2}$ & $\chi^{2}$ & RMSE \\
\hline \multirow[t]{15}{*}{ Ngumvu (IB) } & Newton & \multirow[t]{5}{*}{140} & 0,8996 & 0,01154 & 0,10742 \\
\hline & Two terms & & 0,93452 & 0,0079 & 0,08887 \\
\hline & Midillii & & 0,99434 & 0,00066 & 0,02582 \\
\hline & $\begin{array}{l}\text { Henderson and } \\
\text { Padis }\end{array}$ & & 0,93452 & 0,00755 & 0,08687 \\
\hline & Demir and al. & & 0,9946 & 0,00065 & 0,002552 \\
\hline & Newton & \multirow[t]{5}{*}{280} & 0,85758 & 0,01419 & 0,11912 \\
\hline & Two terms & & 0,88529 & 0,01254 & 0,11196 \\
\hline & Midilli & & 0,97252 & 0,00291 & 0,05393 \\
\hline & $\begin{array}{l}\text { Henderson and } \\
\text { Padis }\end{array}$ & & 0,88529 & 0,01178 & 0,10852 \\
\hline & Demir and al. & & 0,97248 & 0,00301 & 0,05483 \\
\hline & Newton & \multirow[t]{5}{*}{420} & 0,94347 & 0,00713 & 0,08444 \\
\hline & Two terms & & 0,96214 & 0,00608 & 0,07796 \\
\hline & Midilli & & 0,98661 & 0,00197 & 0,04439 \\
\hline & $\begin{array}{l}\text { Henderson and } \\
\text { Padis }\end{array}$ & & 0,96214 & 0,00514 & 0,07172 \\
\hline & Demir and al. & & 0,95999 & 0,00642 & 0,08014 \\
\hline Mb. Menga & Newton & 140 & 0,87559 & 0,01464 & 0,12101 \\
\hline
\end{tabular}


Citation: Laurette Brigelia NKELETELA1, et al., Evaluation of the parameters of the radioactive and convective drying of three cultivars of yam (Dioscorea alata L.). Australian Journal of Basic and Applied Sciences, 13(6): 130-140. DOI: 10.22587/ajbas.2019.13.6.15

\begin{tabular}{|c|c|c|c|c|c|}
\hline \multirow[t]{14}{*}{ (IV) } & Two terms & & 0,92063 & 0,01004 & 0,10021 \\
\hline & Midilli & & 0,99038 & 0,00119 & 0,03446 \\
\hline & $\begin{array}{l}\text { Hendersont } \\
\text { and Padis }\end{array}$ & & 0,92063 & 0,00956 & 0,09779 \\
\hline & Demir and al. & & 0,80184 & 0,02507 & 0,15834 \\
\hline & Newton & \multirow[t]{5}{*}{280} & 0,88001 & 0,01563 & 0,12502 \\
\hline & Two terms & & 0,92029 & 0,01202 & 0,10964 \\
\hline & Midilli & & 0,98714 & 0,00184 & 0,04292 \\
\hline & $\begin{array}{l}\text { Henderson and } \\
\text { Padis }\end{array}$ & & 0,92029 & 0,01088 & 0,10429 \\
\hline & Demir and al. & & 0,9853 & 0,00222 & 0,04709 \\
\hline & Newton & \multirow[t]{5}{*}{420} & 0,91353 & 0,01209 & 0,10995 \\
\hline & Two terms & & 0,93755 & 0,01164 & 0,10789 \\
\hline & Midilli & & 0,979 & 0,00353 & 0,05936 \\
\hline & $\begin{array}{l}\text { Henderson and } \\
\text { Padis }\end{array}$ & & 0,93755 & 0,00952 & 0,09759 \\
\hline & Demir and al. & & 0,98054 & 0,00363 & 0,06022 \\
\hline \multirow[t]{15}{*}{ Nkula (IVB) } & Newton & \multirow[t]{5}{*}{140} & 0,88965 & 0,01256 & 0,11208 \\
\hline & Two terms & & 0,93028 & 0,00858 & 0,09263 \\
\hline & Midilli & & 0,99406 & 0,000712 & 0,02669 \\
\hline & $\begin{array}{l}\text { Henderson and } \\
\text { Padis }\end{array}$ & & 0,93028 & 0,00814 & 0,09022 \\
\hline & Demir and al. & & 0,99421 & 0,000711 & 0,02668 \\
\hline & Newton & \multirow[t]{5}{*}{280} & 0,85599 & 0,01991 & 0,1411 \\
\hline & Two terms & & 0,89387 & 0,01699 & 0,13034 \\
\hline & Midilli & & 0,96554 & 0,00524 & 0,07239 \\
\hline & $\begin{array}{l}\text { Henderson and } \\
\text { Padis }\end{array}$ & & 0,89387 & 0,01537 & 0,12398 \\
\hline & Demir and al. & & 0,96632 & 0,00539 & 0,07343 \\
\hline & Newton & \multirow[t]{5}{*}{420} & 0,91481 & 0,01146 & 0,10704 \\
\hline & Two terms & & 0,93656 & 0,0128 & 0,11313 \\
\hline & Midilli & & 0,97379 & 0,00353 & 0,05938 \\
\hline & $\begin{array}{l}\text { Henderson and } \\
\text { Padis }\end{array}$ & & 0,93656 & 0,0096 & 0,09798 \\
\hline & Demir and al. & & 0,98026 & 0,00398 & 0,06311 \\
\hline
\end{tabular}

The analysis statistics of the data shows that the values of coefficient of determination, the khi-square and RMSE vary from 0, 80184 to 0,9946 ; from 0,02507 to 0,00065 and 0,15834 to 0,002552 .

Indeed, the highest value of the coefficient of determination $\mathrm{R}^{2}(0,9946)$ and the lower values of khi-square $(0,00065)$ and RMSE $(0,002552)$ are obtained by the model of Demir and al. who simulates best the water content reduced of the cultivar Ngumvu to a power of $140 \mathrm{~W}$ during drying radiated. This model is followed by Midilli-Kucuk for same the cultivar and with the same power with $\mathrm{R}^{2}=0,99434$, the khi-square $=0,00066$ and $\mathrm{RMSE}=0,02582$.

Same model (Demir and al.) generate bad adjustments for all the models with a power of $140 \mathrm{~W}$ of the cultivar Mbungu-menga with a coefficient of weaker determination of about 0,80184 and the Khi-square $(0,02507)$, RMSE $(0,15834)$ very high.

\subsubsection{Modeling of the water content reduced during convective drying}

The values of the statistical parameters used to consider the effectiveness of the models semi-empirical for better describing the behavior of different the cultivars from yam (Ngumvu, Mbungu-menga and Nkula), during convective drying, are presented in table 5 .

The analysis of the data shows that the values of coefficient of determination, the khi-square and RMSE vary from 0,94203 to 0 , 99975; from 0,00563 to 0,00002 and 0,07502 to 0,00505 .

Indeed, the highest value of the coefficient of determination $\mathrm{R}^{2}(0,99975)$ and the lower values of khi-square $(0,00002)$ and RMSE $(0,00505)$ do not give good adjustment and do not correspond to any model. They are followed by $\mathrm{R}^{2}(0,99974)$ and khisquare (0,000236), RMSE (0,00486).

After that, the high value of the coefficient of determination $\mathrm{R}^{2}(0,99974)$ and weakest of khi-square $(0,0000286)$, RMSE $(0$, 00535) are obtained by the model of Demir and al. who simulates best the water content reduced of the cultivar Mbungu-menga at a temperature of $80^{\circ} \mathrm{C}$ during convective drying.

Same model (Demir and al.) simulate the cultivar Nkula at a temperature of $60^{\circ} \mathrm{C}$ (with $\mathrm{R}^{2}=0,99967$; khi-square $=0,0000319$ and $\mathrm{RMSE}=0,00565)$ and of $80^{\circ} \mathrm{C}\left(\mathrm{R}^{2}=0,99965\right.$; khi-square $=0,000039$ and $\left.\mathrm{RMSE}=0,00625\right)$, which implies that convective drying is influenced much by the Demir model and al. 
The Newton model generates bad adjustments for all the models at a temperature of $70^{\circ} \mathrm{C}$ of the cultivar Ngumvu with a coefficient of weaker determination of about 0,94203 and the Khi-square $(0,00563)$, RMSE $(0,07502)$ very high.

Table 5: values of the statistical parameters of the models during convective drying

\begin{tabular}{|c|c|c|c|c|c|}
\hline Cultivar & Mode & Temperature $\left({ }^{\circ} \mathrm{C}\right)$ & $\mathbf{R}^{2}$ & $\chi^{2}$ & RMSE \\
\hline \multirow[t]{15}{*}{ Ngumvu (IB) } & Newton & \multirow[t]{5}{*}{60} & 0,95372 & 0,00421 & 0,0649 \\
\hline & Two terms & & 0,96554 & 0,0034 & 0,05835 \\
\hline & Midilli & & 0,98961 & 0,0009 & 0,03159 \\
\hline & $\begin{array}{l}\text { Henderson and } \\
\text { Padis }\end{array}$ & & 0,96554 & 0,00322 & 0,05675 \\
\hline & Demir and al. & & 0,99974 & 0,00002 & 0,00505 \\
\hline & Newton & \multirow[t]{5}{*}{70} & 0,94203 & 0,00563 & 0,07502 \\
\hline & Two terms & & 0,95188 & 0,00525 & 0,07249 \\
\hline & Midilli & & 0,99597 & 0,0004229 & 0,02056 \\
\hline & $\begin{array}{l}\text { Henderson and } \\
\text { Padis }\end{array}$ & & 0,95188 & 0,00485 & 0,06964 \\
\hline & Demir and al. & & 0,99613 & 0,0004228 & 0,02056 \\
\hline & Newton & \multirow[t]{5}{*}{80} & 0,96682 & 0,00324 & 0,05694 \\
\hline & Two terms & & 0,97582 & 0,0027 & 0,05196 \\
\hline & Midilli & & 0,99892 & 0,000115 & 0,01073 \\
\hline & $\begin{array}{l}\text { Henderson and } \\
\text { Padis }\end{array}$ & & 0,97582 & 0,00246 & 0,04965 \\
\hline & Demir and al. & & 0,99917 & 0,0000924 & 0,00961 \\
\hline \multirow{15}{*}{$\begin{array}{l}\text { Mb. Menga } \\
\text { (IV) }\end{array}$} & Newton & \multirow[t]{5}{*}{60} & 0,95634 & 0,00394 & 0,06276 \\
\hline & Two terms & & 0,96673 & 0,00327 & 0,05715 \\
\hline & Midilli & & 0,99921 & 0,0000754 & 0,00869 \\
\hline & $\begin{array}{l}\text { Henderson and } \\
\text { Padis }\end{array}$ & & 0,96673 & 0,00309 & 0,05554 \\
\hline & Demir and al. & & 0,99924 & 0,0000748 & 0,00865 \\
\hline & Newton & \multirow[t]{5}{*}{70} & 0,95745 & 0,00409 & 0,06398 \\
\hline & Two terms & & 0,9669 & 0,00358 & 0,05984 \\
\hline & Midilli & & 0,99737 & 0,000273 & 0,01653 \\
\hline & $\begin{array}{l}\text { Henderson and } \\
\text { Padis }\end{array}$ & & 0,9669 & 0,00331 & 0,0575 \\
\hline & Demir and al. & & 0,99746 & 0,000274 & 0,01657 \\
\hline & Newton & \multirow[t]{5}{*}{80} & 0,9601 & 0,00376 & 0,06131 \\
\hline & Two terms & & 0,96762 & 0,00351 & 0,05923 \\
\hline & Midilli & & 0,9854 & 0,00151 & 0,0388 \\
\hline & $\begin{array}{l}\text { Henderson and } \\
\text { Padis }\end{array}$ & & 0,96762 & 0,00319 & 0,05647 \\
\hline & Demir and al. & & 0,99974 & 0,0000286 & 0,00535 \\
\hline \multirow[t]{15}{*}{ Nkula (IVB) } & Newton & \multirow[t]{5}{*}{60} & 0,96663 & 0,00297 & 0,05451 \\
\hline & Two terms & & 0,97503 & 0,00243 & 0,04931 \\
\hline & Midilli & & 0,99975 & 0,0000236 & 0,00486 \\
\hline & $\begin{array}{l}\text { Henderson and } \\
\text { Padis }\end{array}$ & & 0,97503 & 0,00229 & 0,04784 \\
\hline & Demir and al. & & 0,99967 & 0,0000319 & 0,00565 \\
\hline & Newton & \multirow[t]{5}{*}{70} & 0,96053 & 0,00365 & 0,06039 \\
\hline & Two terms & & 0,9707 & 0,00305 & 0,05519 \\
\hline & Midilli & & 0,99949 & 0,0000504 & 0,0071 \\
\hline & $\begin{array}{l}\text { Henderson and } \\
\text { Padis }\end{array}$ & & 0,9707 & 0,00281 & 0,05303 \\
\hline & Demir and al. & & 0,99942 & 0,00006 & 0,00775 \\
\hline & Newton & \multirow[t]{5}{*}{80} & 0,96352 & 0,00354 & 0,0595 \\
\hline & Two terms & & 0,97437 & 0,00284 & 0,05332 \\
\hline & Midilli & & 0,99952 & 0,0000508 & 0,00713 \\
\hline & $\begin{array}{l}\text { Henderson and } \\
\text { Padis }\end{array}$ & & 0,97437 & 0,0026 & 0,05094 \\
\hline & Demir and al. & & 0,99965 & 0,000039 & 0,00625 \\
\hline
\end{tabular}


Table 6 : models semi-empirical according to the mode of drying of three varieties of Dioscorea alata L. yams

\begin{tabular}{|l|l|l|}
\hline Mode of drying & Expression of the model & Reference \\
\hline Radiative & $\mathrm{MR}=3,2707 \exp \left(-4,97 \times 10^{-4} \mathrm{t}\right)^{0,6142}-2,20607$ & Demir and al. \\
& $\mathrm{R}^{2}=0,9946 ; \chi^{2}=0,00065 ; \mathrm{RMSE}=0,002552$ & \\
\hline convective & $\mathrm{MR}=1,69101 \exp (-0,0041 \mathrm{t})^{0,95397}-0,69502$ & Demir and al. \\
& $\mathrm{R}^{2}=0,99974 ; \chi^{2}=0,0000286 ; \mathrm{RMSE}=0,00535$ & \\
\hline
\end{tabular}

\section{Conclusion}

This work focuses on the radiative and convective drying of three yam cultivars Dioscorea alata produced in the Madingou District of Congo. The results showed that, power and temperature have an influence on drying kinetics; the diffusion coefficient and activation energy.

Power is the main factor that significantly reduces drying time. Radiative drying takes place in two phases: warming up and decaying. Only the decreasing phase is present in the convective drying. The cultivar Nkula (white purple yam) has a significant influence on both drying modes. Among the semi-empirical mathematical models used, the 'Demir and al' model seems the most appropriate for describing the drying behavior of the three yam cultivars.

Thus, the experimental conditions (microwave oven and oven) studied allowed us to stabilize the power and drying temperature of these three cultivars because at a power of $140 \mathrm{~W}$ and a temperature of $80^{\circ} \mathrm{C}$ only Demir influenced radiative and convective drying.

\section{Bibliographical references}

Akpinar E.K. and Bicer Y., 2008. 'Mathematical Modelling of Thin to bush-hammer Drying Process of Long Green Pepper in Solar Dryer and Open Under Sun ', Energy Conversion and Management, vol. 49, Nº6, pages. 1367 - 1375.

Amina Menasra and al., 2015. Contributing to the convective drying of Aurès green oak glands (Quercus ilex), $5^{\text {th }}$ Maghrebian Seminar on Drying Sciences and Technologies (SMSTS'2015) Ouargla (Algeria) Pages 6.

Doymaz I. and P. Mehmet, 2002. The effects of dipping pretreatments one air-drying spleens of the seedless grapes, Newspaper of Food Engineering, Vol. 52, Pages 413-417.

Doymaz I., 2006. ' Thin- To bush-hammer Drying Behavior of Mint Leaves (Mentha Spicata L) ', Newspaper of Food Engineering, vol. 74, pages. 370 - 375 .

Goyal R.K., A.R.P.Kingsly, M.R.Manikantan and S.M. Ilyas, 2007. Mathematical modelling of thin to bush-hammer drying kinetics of plum in A tunnel dryer, Newspaper of Food Engineering, Vol. 79, Pages 176-180.

Hao-Yuju et al., 2015. Kinetics of drying and change of the internal temperature and the distribution of the moisture of the sample of sections of yam during drying by convection with the hot air, vol. $34\left(\mathrm{~N}^{\circ} 3\right)$.

Lahmari N, Fahloul D. and Azani I., 2012. Influence of the methods of drying on quality of tomatoes speeches (Zahra variety), Re-examined Renewable Energies, Vol.15, N², Pages 285-295.

Srikiatden J. and Roberts J.S., 2006. 'Measuring Moisture Diffusivity of Potato and Carrot (Core and Cortex) during Convective Hot Air and Isothermal Drying ', Newspaper of Food Engineering, vol. 74, №1, pp. 143 - 152.

Tulek Y., 2011. Drying kinetics of oyster mushroom in A convective hot air dryer, Newspaper of Agricultural Science and Technology, Vol.13, Pages 655-664. 